\section{A) Check for updates}

Cite this: Dalton Trans., 2018, 47 15530

Received 19th September 2018, Accepted 15th October 2018

DOI: $10.1039 / c 8 d t 03793 k$

rsc.li/dalton

\title{
Cages on a plane: a structural matrix for molecular 'sheets' $\uparrow$
}

\author{
Hector W. L. Fraser, (DD a Gary S. Nichol, (ID) a Amgalanbaatar Baldansuren, (DD b \\ Eric J. L. Mclnnes (D) ${ }^{b}$ and Euan K. Brechin (D) *a
}

\begin{abstract}
A family of heterometallic Anderson-type 'wheels' of general formula $\left[\mathrm{M}_{2}^{\prime \prime \prime} \mathrm{M}_{5}^{\prime \prime}(\mathrm{hmp})_{12}\right]^{4+}\left(\mathrm{M}^{\prime \prime \prime}=\mathrm{Cr}\right.$ or $\mathrm{Al}$ and $\mathrm{M}^{\prime \prime}=\mathrm{Ni}$ or $\mathrm{Zn}, \mathrm{Hhmp}=2$-pyridinemethanol) has been extended to include $\mathrm{M}^{\prime \prime \prime}=\mathrm{Cr}$ or $\mathrm{Al}$ and $\mathrm{M}^{\prime \prime}=\mathrm{Co}$, $\mathrm{Fe}, \mathrm{Mn}$ or $\mathrm{Cu}$, affording five new species of formulae $\left[\mathrm{Cr}_{2} \mathrm{CO}_{5}(\mathrm{hmp})_{12}\right]\left(\mathrm{ClO}_{4}\right)_{4}(\mathbf{1}),\left[\mathrm{Cr}_{2} \mathrm{Fe}_{5}(\mathrm{hmp})_{12}\right]\left(\mathrm{ClO}_{4}\right)_{4}$ (2), $\left[\mathrm{Cr}_{2} \mathrm{Mn}_{5}(\mathrm{hmp})_{12}\right]\left(\mathrm{ClO}_{4}\right)_{4}$ (3), $\left[\mathrm{Cr}_{2} \mathrm{Cu}_{5}(\mathrm{hmp})_{12}\right]\left(\mathrm{ClO}_{4}\right)_{2}\left(\mathrm{NO}_{3}\right)_{2}(4)$ and $\left[\mathrm{Al}_{2} \mathrm{CO}_{5}(\mathrm{hmp})_{12}\right]\left(\mathrm{ClO}_{4}\right)_{4}$ (5). As per previous family members, the metallic skeleton common to the cations of $\mathbf{1 - 5}$ describes a centred hexagon with the two $M^{\prime \prime \prime}$ sites disordered around the outer wheel, with the exception of compound 4 where the $\mathrm{Cu}^{\prime \prime}$ sites are localised. A structurally related, but enlarged planar disc possessing a $\left[\mathrm{M}_{6}^{\prime \prime \prime} \mathrm{M}^{\prime \prime}\right]$ hexagon capped on each edge by a $\mathrm{Cu}^{\prime \prime}$ ion can be formed, but only when $\mathrm{M}^{\prime \prime \prime}=\mathrm{Al}$ and $\mathrm{M}^{\prime \prime}=\mathrm{Cu}$. In $\left[\mathrm{Al}_{6}^{\mathrm{III}} \mathrm{Cu} / \mathrm{O}(\mathrm{OH})_{12}(\mathrm{hmp})_{12}\right]\left(\mathrm{ClO}_{4}\right)_{6}\left(\mathrm{NO}_{3}\right)_{2}(6)$ the Anderson moiety contains a central, symmetry-imposed octahedral $\mathrm{Cu}^{\prime \prime}$ ion surrounded by a wheel of $\mathrm{Al}^{\mathrm{III}}$ ions. Solid-state dc susceptibility and magnetisation measurements reveal the presence of competing exchange interactions in $\mathbf{1 - 5}$, and very weak antiferromagnetic exchange between the $\mathrm{Cu}^{\prime \prime}$ ions in $\mathbf{6}$ which may be intra- and/or intermolecular in nature.
\end{abstract}

\section{Introduction}

Paramagnetic metal ions arranged in triangular topologies have long held academic interest in the field of moleculebased magnetism, ${ }^{1}$ since they can lead to the observation of, for example, ferromagnetic exchange in partial cubanes, ${ }^{2}$ tuneable exchange between metal ions separated by two atom bridges, ${ }^{3}$ antisymmetric exchange effects in heterometallic $3 \mathrm{~d}-$ $4 \mathrm{~d}$ complexes, ${ }^{4}$ and geometric spin frustration in antiferromagnetically coupled cages ${ }^{5}$ and $2-3 \mathrm{D}$ materials (e.g. the kagomé lattice) possessing high symmetry. ${ }^{6}$

In $3 \mathrm{~d}$ transition metal chemistry the molecular triangle is most commonly found in one of two structure types: (a) the oxo-centred planar triangle $\left[\mathrm{M}_{3} \mathrm{O}\right]^{n+}$, as personified by the basic metal carboxylates, ${ }^{7}$ where all four atoms lie on (or nearly on) the same plane, or (b) the $\left[\mathrm{M}_{3} \mathrm{O}_{4}\right]^{n+}$ partial cubane where the metal ions and $\mathrm{O}$-atoms lie on different planes, i.e. a cube missing one metal vertex. The latter moiety also often

\footnotetext{
${ }^{a}$ EaStCHEM School of Chemistry, The University of Edinburgh, David Brewster Road, Edinburgh, EH9 3FJ Scotland, UK. E-mail: E.Brechin@ed.ac.uk; Tel: +44 (0)131-650-7545

${ }^{b}$ School of Chemistry and Photon Science Institute, The University of Manchester, Oxford Road, Manchester, M13 9PL, UK

$\dagger$ Electronic supplementary information (ESI) available: Additional details of X-ray crystallography and structure, and magnetic measurements. CCDC 1855222-1855227. For ESI and crystallographic data in CIF or other electronic format see DOI: 10.1039/c8dt03793k
}

acts as the building block for the creation of large and (occasionally) very large molecules whose structures conform to molecular 'sheets', i.e. the metallic skeleton of the complex grows in 2D. From a structural/synthetic perspective this is simple to understand as a series of O-bridged, edge- and vertex-sharing metal triangles (Fig. 1). For example, two edgesharing triangles form tetranuclear $\left[\mathrm{M}_{4} \mathrm{O}_{2}\right]^{n+}$ or $\left[\mathrm{M}_{4} \mathrm{O}_{6}\right]^{n+}$ butterflies or partial cubanes (Fig. 1a and b), with detailed magneto-structural correlations developed for $\mathrm{Fe}^{8}$ and $\mathrm{Mn} .{ }^{9}$ Such triangles and butterflies/partial cubanes are by far the most common building blocks seen in large cages containing multiple $3 \mathrm{~d} \mathrm{M}_{n}^{\mathrm{II} / \mathrm{III}}$ ions $(n>4)$.

Continued edge-sharing growth in just one dimension/ direction from triangle to butterfly/partial cubane to larger species results in the formation of molecular rods (Fig. 1c), a pertinent example being the use of tripodal alcohol ligands to direct the formation of $\mathrm{Mn}_{6}, \mathrm{Mn}_{7}, \mathrm{Mn}_{8}, \mathrm{Mn}_{12}$ complexes. ${ }^{10}$ Growth in two dimensions/directions leads to planar disc-like complexes (Fig. 1d-i), the most common of which is the Anderson-type wheel. This structure describes a centred hexagon, with homometalic, ${ }^{11}$ heterometallic, ${ }^{12}$ homovalent ${ }^{13}$ and heterovalent ${ }^{14}$ examples known. Larger complexes are somewhat unusual, but are all characterised by beautiful structural aesthetics, the presence of the Anderson moiety at the core of their metallic skeletons, and interesting physical properties. For example, $\left[\mathrm{Ni}_{10}\right]$ (Fig. 1e) is a rare example of a large nuclearity Ni single-molecule magnet (SMM), ${ }^{15}$ mixed-valent $\left[\mathrm{Co}_{13 / 14}\right]$ cages (Fig. 1f and g) display ferromagnetic exchange 
a)

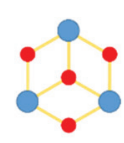

b)

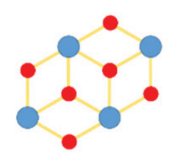

c)

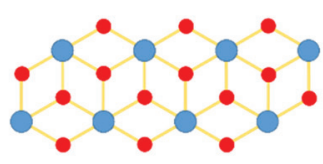

d)

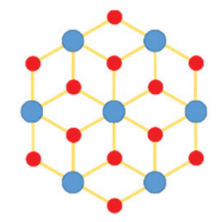

e)

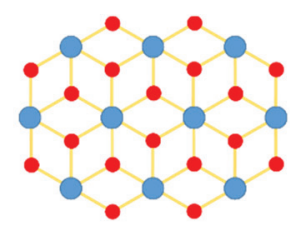

f)

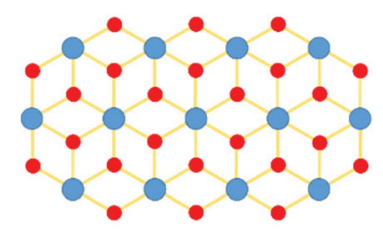

g)

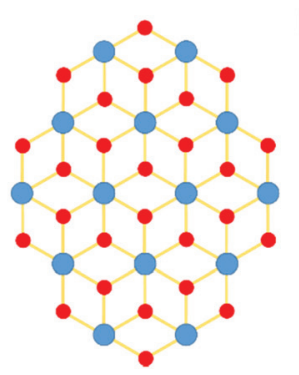

h)

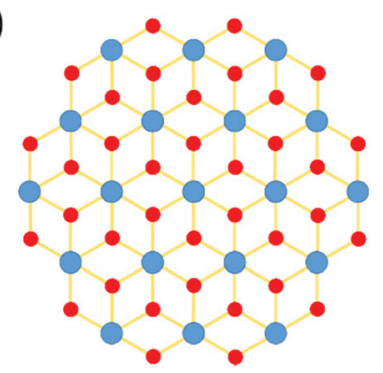

i)

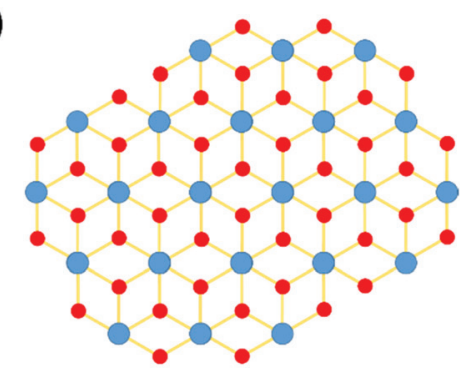

Fig. 1 Schematic showing the metal oxygen cores of a variety of transition metal cages based on triangular $\left[\mathrm{M}_{3}\right]$ building blocks; $(a)\left[\mathrm{M}_{3} \mathrm{O}_{4}\right]^{\text {n+ }}$ partial cubane, (b) $\left[\mathrm{M}_{4} \mathrm{O}_{6}\right]^{n+}$ butterfly, (c) molecular rod, (d) Anderson-type wheel, (e) $\left[\mathrm{Ni}_{10}\right]$, (f) $\left[\mathrm{Co}_{13}\right],(\mathrm{g})\left[\mathrm{Co}_{14}\right]$, (h) $\left[\mathrm{Mn}_{19}\right]$, (i) $\left[\mathrm{Co}_{24}\right]$ showing only the 22 metal sites sitting on the same plane.

interactions between the $\mathrm{Co}^{\mathrm{II}}$ ions, ${ }^{16}\left[\mathrm{Fe}_{17 / 19}\right]$ is an example of a trapped/molecular mineral phase with $S \geq 33 / 2,{ }^{17}$ two $\left[\mathrm{Mn}_{19}\right]$ cages possess a similar brucite-like core (Fig. 1h), one displaying intramolecular ferrimagnetic exchange and long range magnetic order, ${ }^{18 a}$ and the other being a very rare example of a $\mathrm{Mn}$-alkoxide, while $\left[\mathrm{CO}_{24}\right]$ was the first polynuclear $\mathrm{Co}^{\mathrm{II}}$ species to exhibit slow relaxation of the magnetization (Fig. 1i). ${ }^{19}$ It is also interesting to note a common thread in the synthesis of each of these species: the use of alkoxide-based bridging ligands.

We recently reported a small family of Anderson-type complexes of general formula $\left[\mathrm{M}_{2}^{\mathrm{III}} \mathrm{M}_{5}^{\mathrm{II}}(\mathrm{hmp})_{12}\right]^{4+}\left(\mathrm{M}^{\mathrm{III}}=\mathrm{Cr}\right.$ or Al and $\mathrm{M}^{\mathrm{II}}=\mathrm{Ni}$ or $\mathrm{Zn}, \mathrm{Hhmp}=2$-pyridinemethanol) in which the two $\mathrm{M}^{\mathrm{III}}$ sites were disordered around the outer wheel. ${ }^{20}$ The relative ease of synthesis of these species and their stability in both the solid and solution state suggested that more family members could be made simply by changing the identity of both the $\mathrm{M}^{\mathrm{III}}$ and $\mathrm{M}^{\mathrm{II}}$ ions. Herein we report expansion of this family to include $\mathrm{M}^{\mathrm{II}}=\mathrm{Cu}, \mathrm{Co}, \mathrm{Mn}$ and $\mathrm{Fe}$, and $\mathrm{M}^{\mathrm{III}}=\mathrm{Al}$ and $\mathrm{Cr}$, alongside the serendipitous self-assembly of the related, but larger complex $\left[\mathrm{Al}_{6}^{\mathrm{III}} \mathrm{Cu}\right.$

\section{Experimental}

\section{Materials and physical measurements}

All chemicals were procured from commercial suppliers and used as received (reagent grade). Elemental analyses for C, H, $\mathrm{N}$ and metal ions were performed by Medac Ltd.

\section{Synthesis of $\left[\mathrm{Cr}_{2} \mathrm{Co}_{5}(\mathrm{hmp})_{12}\right]\left(\mathrm{ClO}_{4}\right)_{4} \cdot \mathbf{9 M e O H}(1)$}

$\mathrm{Co}\left(\mathrm{ClO}_{4}\right)_{2} \cdot 6 \mathrm{H}_{2} \mathrm{O}(0.366 \mathrm{~g}, 1 \mathrm{mmol})$ and $\mathrm{CrCl}_{3} \cdot 6 \mathrm{H}_{2} \mathrm{O}(0.133 \mathrm{~g}$, $0.5 \mathrm{mmol})$ were dissolved with NaOMe $(0.162 \mathrm{~g}, 3 \mathrm{mmol})$ in $\mathrm{MeOH}(24 \mathrm{ml})$ to give a clear brown solution. Upon full dissolution, Hhmp $(0.285 \mathrm{ml}, 3 \mathrm{mmol})$ was added dropwise giving a colour change to red. The reaction was left overnight with continuous stirring. $12 \mathrm{ml}$ samples of the resulting dark red solution were heated in Teflon-lined autoclaves at $100{ }^{\circ} \mathrm{C}$ for 12 hours. After slowly cooling to room temperature the reaction vessels were allowed to sit undisturbed for 24 hours yielding dark pink, block-shaped crystals suitable for X-ray diffraction. Yield $0.139 \mathrm{~g}$ (26.6\% by Co weight). Anal. Calcd (\%) for $\mathrm{C}_{79} \mathrm{H}_{100} \mathrm{Cl}_{4} \mathrm{Co}_{5} \mathrm{Cr}_{2} \mathrm{~N}_{12} \mathrm{O}_{35}$ : C $40.93, \mathrm{H}$ 4.35, Cr 4.49, Co 12.71, N 7.25; found: C 40.21, H 4.36, Cr 4.88, Co 12.36, $\mathrm{N} 7.43$.

\section{Synthesis of $\left[\mathrm{Cr}_{2} \mathrm{Fe}_{5}(\mathrm{hmp})_{12}\right]\left(\mathrm{ClO}_{4}\right)_{4} \cdot 9 \mathrm{MeOH}(2)$}

$\mathrm{Fe}\left(\mathrm{ClO}_{4}\right)_{2} \cdot 6 \mathrm{H}_{2} \mathrm{O} \quad(0.363 \mathrm{~g}, \quad 1 \mathrm{mmol})$ and $\mathrm{Cr}\left(\mathrm{ClO}_{4}\right)_{3} \cdot 6 \mathrm{H}_{2} \mathrm{O}$ $(0.229 \mathrm{~g}, 0.5 \mathrm{mmol})$ were dissolved with $\mathrm{NaOMe}(0.162 \mathrm{~g}$, $3 \mathrm{mmol})$ in $\mathrm{MeOH}(24 \mathrm{ml})$ to give a dark red solution. Upon full dissolution, Hhmp $(0.285 \mathrm{ml}, 3 \mathrm{mmol})$ was added dropwise and the reaction left overnight with continuous stirring. $12 \mathrm{ml}$ samples of the resulting dark brown solution were heated in Teflon-lined autoclaves at $100{ }^{\circ} \mathrm{C}$ for 12 hours. After slowly cooling to room temperature the reaction vessels were allowed to sit undisturbed for 24 hours yielding dark brown, plate-shaped crystals suitable for X-ray diffraction. Yield $0.041 \mathrm{~g} \quad(8.7 \%$ by $\mathrm{Fe}$ weight). Anal. Calcd (\%) for $\mathrm{C}_{84} \mathrm{H}_{80} \mathrm{Cl}_{4} \mathrm{Cr}_{2} \mathrm{Fe}_{5} \mathrm{~N}_{12} \mathrm{O}_{30}: \mathrm{C}$ 44.59, H 3.56, Cr 4.60, Fe 12.34, N 7.43; found: C 44.36, H 3.60, Cr 4.95, Fe 12.01, N 7.43.

\section{Synthesis of $\left[\mathrm{Cr}_{2} \mathrm{Mn}_{5}(\mathrm{hmp})_{12}\right]\left(\mathrm{ClO}_{4}\right)_{4} \cdot 10 \mathrm{MeOH}(3)$}

$\mathrm{Mn}\left(\mathrm{ClO}_{4}\right)_{2} \cdot 6 \mathrm{H}_{2} \mathrm{O}(0.365 \mathrm{~g}, 1 \mathrm{mmol})$ and $\mathrm{Cr}\left(\mathrm{ClO}_{4}\right)_{3} \cdot 6 \mathrm{H}_{2} \mathrm{O}$ $(0.229 \mathrm{~g}, 0.5 \mathrm{mmol})$ were dissolved with NaOMe $(0.162 \mathrm{~g}$, $3 \mathrm{mmol})$ in $\mathrm{MeOH}(24 \mathrm{ml})$ to give a light pink cloudy solution. Upon full dissolution, Hhmp $(0.285 \mathrm{ml}, 3 \mathrm{mmol})$ was added dropwise and the reaction was left overnight with continuous stirring. $12 \mathrm{ml}$ samples of the resulting dark purple/red solution were heated in Teflon-lined autoclaves at $100{ }^{\circ} \mathrm{C}$ for 12 hours. After slowly cooling to room temperature the reaction vessels were allowed to sit undisturbed for 24 hours yielding pale purple hexagonal crystals suitable for X-ray diffrac- 
tion. Yield $0.021 \mathrm{~g}$ (4.4\% by $M_{\mathrm{n}}$ weight). Anal. Calcd (\%) for $\mathrm{C}_{72} \mathrm{H}_{72} \mathrm{Cl}_{4} \mathrm{Cr}_{2} \mathrm{Mn}_{5} \mathrm{~N}_{12} \mathrm{O}_{28}$ : C 41.70, H 3.50, Cr 5.01, Mn 13.25, N 8.10; found: C 41.52, H 3.66, Cr 4.98, Mn 13.02, N 8.33.

\section{Synthesis of $\left[\mathrm{Cr}_{2} \mathrm{Cu}_{5}(\mathrm{hmp})_{12}\right]\left(\mathrm{ClO}_{4}\right)_{2}\left(\mathrm{NO}_{3}\right)_{2} \cdot 16 \mathrm{MeOH}(4)$}

$\mathrm{Cu}\left(\mathrm{ClO}_{4}\right)_{2} \cdot 6 \mathrm{H}_{2} \mathrm{O} \quad(0.371 \mathrm{~g}, 1 \mathrm{mmol})$ and $\mathrm{Cr}\left(\mathrm{NO}_{3}\right)_{3} \cdot 9 \mathrm{H}_{2} \mathrm{O}$ (0.200 g, $0.5 \mathrm{mmol})$ were dissolved with $\mathrm{NaOMe}(0.162 \mathrm{~g}$, $3 \mathrm{mmol}$ ) in $\mathrm{MeOH}(24 \mathrm{ml})$ to give a pale green solution. Upon full dissolution, Hhmp $(0.285 \mathrm{ml}, 3 \mathrm{mmol})$ was added dropwise giving a colour change to dark green/blue. The reaction was left overnight with continuous stirring. $12 \mathrm{ml}$ samples of the resulting dark green solution were heated in Teflon-lined autoclaves at $100{ }^{\circ} \mathrm{C}$ for 12 hours. After slowly cooling to room temperature the reaction vessels were allowed to sit undisturbed for 24 hours and the resulting solutions were left to slowly evaporate over 5 days, yielding light purple, plate-shaped crystals suitable for X-ray diffraction. Yield $0.104 \mathrm{~g}(20.4 \%$ by $\mathrm{Cu}$ weight). Anal. Calcd (\%) for $\mathrm{C}_{72} \mathrm{H}_{72} \mathrm{Cl}_{2} \mathrm{Cr}_{2} \mathrm{Cu}_{5} \mathrm{~N}_{14} \mathrm{O}_{26}: \mathrm{C}$ 42.35, $\mathrm{H}$ 3.55, Cr 5.09, $\mathrm{Cu}$ 15.56, N 9.60; found: C 41.85, H 3.40, Cr 5.09, Cu 15.38, N 9.37.

\section{Synthesis of $\left[\mathrm{Al}_{2} \mathrm{Co}_{5}(\mathrm{hmp})_{12}\right]\left(\mathrm{ClO}_{4}\right)_{4} \cdot 9 \mathrm{MeOH}(5)$}

$\mathrm{Co}\left(\mathrm{ClO}_{4}\right)_{2} \cdot 6 \mathrm{H}_{2} \mathrm{O}(0.366 \mathrm{~g}, 1 \mathrm{mmol})$ and $\mathrm{Al}\left(\mathrm{NO}_{3}\right)_{3} \cdot 9 \mathrm{H}_{2} \mathrm{O}(0.188 \mathrm{~g}$, $0.5 \mathrm{mmol})$ were dissolved with NaOMe $(0.162 \mathrm{~g}, 3 \mathrm{mmol})$ in $\mathrm{MeOH}(24 \mathrm{ml})$ to give a pink solution. Upon full dissolution, Hhmp (0.285 ml, $3 \mathrm{mmol}$ ) was added dropwise giving a colour change to red. The reaction was left overnight with continuous stirring. $12 \mathrm{ml}$ samples of the resulting dark red solution were heated in Teflon-lined autoclaves at $100{ }^{\circ} \mathrm{C}$ for 12 hours. After slowly cooling to room temperature the reaction vessels were allowed to sit undisturbed for 24 hours yielding pale brown, plate-shaped crystals suitable for X-ray diffraction. Yield $0.289 \mathrm{~g}(70.7 \%$ by Co weight). Anal. Calcd (\%) for $\mathrm{C}_{72} \mathrm{H}_{72} \mathrm{Al}_{2} \mathrm{Cl}_{4} \mathrm{Co}_{5} \mathrm{~N}_{12} \mathrm{O}_{28}$ : C 42.31, $\mathrm{H}$ 3.55, Al 2.64, Co 14.42, N 8.22; found: C 41.81, H 3.38, Al 2.50, Co 14.34, N 7.99.

\section{Synthesis of $\left[\mathrm{Cu}_{7} \mathrm{Al}_{6}(\mathrm{hmp})_{12}(\mathrm{OH})_{12}\right]\left(\mathrm{ClO}_{4}\right)_{6}\left(\mathrm{NO}_{3}\right)_{2} \cdot 21 \mathrm{MeOH}(6)$}

$\mathrm{Cu}\left(\mathrm{ClO}_{4}\right)_{2} \cdot 6 \mathrm{H}_{2} \mathrm{O}(0.371 \mathrm{~g}, 1 \mathrm{mmol})$ and $\mathrm{Al}\left(\mathrm{NO}_{3}\right)_{3} \cdot 9 \mathrm{H}_{2} \mathrm{O}(0.188 \mathrm{~g}$, $0.5 \mathrm{mmol})$ were dissolved with NaOMe (0.162 $\mathrm{g}, 3 \mathrm{mmol})$ in $\mathrm{MeOH}(24 \mathrm{ml})$ to give a turquoise solution. Upon full dissolution, Hhmp (0.285 $\mathrm{ml}, 3 \mathrm{mmol})$ was added dropwise giving a colour change to dark blue. The reaction was left overnight with continuous stirring. $12 \mathrm{ml}$ samples of the resulting solution were heated in Teflon-lined autoclaves at $100{ }^{\circ} \mathrm{C}$ for 12 hours. After slowly cooling to room temperature the dark blue solution was left to slowly evaporate yielding dark blue, block-shaped crystals suitable for X-ray diffraction. Yield $0.078 \mathrm{~g}(26.7 \%$ by $\mathrm{Al}$ weight). Anal. Calcd (\%) for $\mathrm{C}_{82} \mathrm{H}_{124} \mathrm{Al}_{6} \mathrm{Cl}_{6} \mathrm{Cu}_{7} \mathrm{~N}_{14} \mathrm{O}_{64}$ : C 31.27, $\mathrm{H}$ 3.97, $\mathrm{Al}$ 5.14, $\mathrm{Cu}$ 14.12, N 6.23; found: C 30.89, H 3.87, $\mathrm{Al} 5.11, \mathrm{Cu} 14.30, \mathrm{~N} 6.20$.

\section{X-ray crystallography}

Single crystal X-ray diffraction data for samples 1-6 were collected using a Rigaku Oxford Diffraction SuperNova diffractometer with $\mathrm{MoK}_{\alpha}$ (1 \& 5-6) or $\mathrm{CuK}_{\alpha}$ (2-4) radiation. Experimental details are given in Table S1 in the ESI. $\dagger$ An
Oxford Cryosystems Cryostream 700+ low temperature device was used to maintain a crystal temperature of $120.0 \mathrm{~K}$ for all experiments. The structures were solved using ShelXT and refined with version ShelXL interfaced through Olex2 (1-2, 4-6), or Superflip and refined using ShelXL (3). ${ }^{21-23}$ All nonhydrogen atoms were refined using anisotropic displacement parameters. $\mathrm{H}$ atoms were placed in calculated positions geometrically and refined using the riding model except for some in compound 6 which were refined freely. CCDC 1855222-1855227.†

\section{Magnetic data}

Magnetic susceptibility and magnetisation measurements were performed on powdered, polycrystalline samples of 1-6 in the $T=2-300 \mathrm{~K}$ and $B=0-7 \mathrm{~T}$ temperature and field ranges on a Quantum Design MPMS XL SQUID magnetometer equipped with a $7 \mathrm{~T}$ dc magnet. Hexadecane was employed to prevent potential torquing of the crystallites. Diamagnetic corrections were applied to all data using Pascal's constants.

\section{EPR spectroscopy}

EPR spectra of 6 were measured at Q-band on a Bruker EMX spectrometer.

\section{Results and discussion}

\section{Structural description}

There are two unique structure types present in 1-6; compounds 1-5 possess the $\left[\mathrm{M}_{7}\right]$ Anderson-type structure, while $\mathbf{6}$ is an $\left[\mathrm{M}_{13}\right]$ cluster containing an Anderson core capped on each of its six edges by an additional metal ion. Crystallographic details for all complexes are given in Table S1, $\dagger$ with pertinent bond lengths and angles provided in Tables 1-3.

Table 1 Pertinent structural parameters for the $M_{\text {central }}-M_{\text {outer }}$ dialkoxo bridge in 1-5. $r=\mathrm{M}-\mathrm{O}$ bond length, $\phi=\mathrm{M}-\mathrm{O}-\mathrm{M}$ bridging angle

\begin{tabular}{llll}
\hline & $\mathrm{M}-\mathrm{M}[\AA]$ & $r[\AA]$ & $\phi\left[^{\circ}\right]$ \\
\hline $\mathbf{1}$ & 3.148 & $2.059-2.151$ & $95.40-98.23$ \\
$\mathbf{2}$ & 3.182 & $2.126-2.162$ & $95.80-98.70$ \\
$\mathbf{3}$ & 3.236 & $2.108-2.170$ & $96.60-98.48$ \\
$\mathbf{4}$ & $3.156-3.188$ & $2.067-2.213$ & $88.59-102.89$ \\
$\mathbf{5}$ & 3.133 & $2.036-2.133$ & $95.49-98.47$
\end{tabular}

Table 2 Pertinent structural parameters for the $M_{\text {outer }}-M_{\text {outer }}$ di-alkoxo bridge in 1-5. $r=\mathrm{M}-\mathrm{O}$ bond length, $\phi=\mathrm{M}-\mathrm{O}-\mathrm{M}$ bridging angle

\begin{tabular}{llll}
\hline & $\mathrm{M}-\mathrm{M}[\AA]$ & $r[\AA]$ & $\phi\left[{ }^{\circ}\right]$ \\
\hline $\mathbf{1}$ & 3.156 & $1.987-2.151$ & $97.09-104.73$ \\
$\mathbf{2}$ & 3.191 & $1.981-2.162$ & $97.92-107.47$ \\
$\mathbf{3}$ & 3.245 & $1.974-2.177$ & $98.67-102.73$ \\
$\mathbf{4}$ & $3.163-3.216$ & $1.571-2.402$ & $91.70-144.85$ \\
$\mathbf{5}$ & 3.141 & $1.956-2.133$ & $97.77-105.81$
\end{tabular}


Table 3 Pertinent structural parameters for the di-alkoxo bridges in compound 6. $r=\mathrm{M}-\mathrm{O}$ bond length, $\phi=\mathrm{M}-\mathrm{O}-\mathrm{M}$ bridging angle

\begin{tabular}{llll}
\hline & $\mathrm{M}-\mathrm{M}[\AA]$ & $r[\AA]$ & $\phi\left[{ }^{\circ}\right]$ \\
\hline $\mathrm{Cu}_{\text {central }}-\mathrm{Al}_{\text {ring }}$ & 2.984 & $1.943-2.043$ & $96.76,96.91$ \\
$\mathrm{Al}_{\text {ring }}-\mathrm{Al}_{\text {ring }}$ & 2.985 & $1.870-1.948$ & $100.18,105.73$ \\
$\mathrm{Al}_{\text {ring }}-\mathrm{Cu}_{\text {outer }}$ & $3.447,3.451$ & $1.866-1.945$ & $129.77,129.89$
\end{tabular}

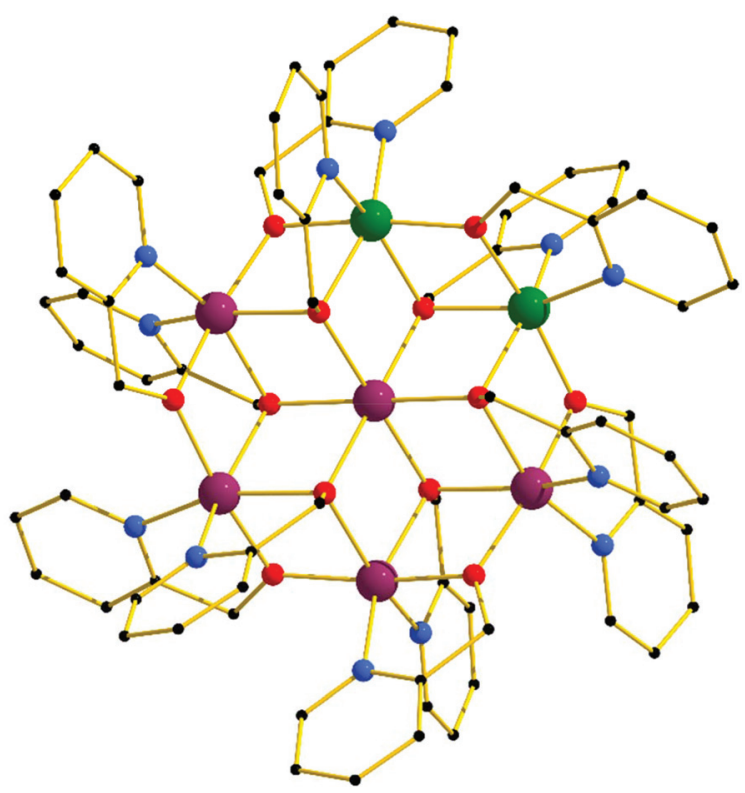

Fig. 2 Molecular structure of the 1,2-isomer of the cation of compound 3. Colour code: $\mathrm{Cr}=$ dark green, $\mathrm{Mn}=$ dark pink, $\mathrm{O}=\mathrm{red}, \mathrm{N}=$ light blue, $\mathrm{C}=$ black. $\mathrm{H}$-atoms, perchlorate counter anions and solvent molecules of crystallisation are omitted for clarity.

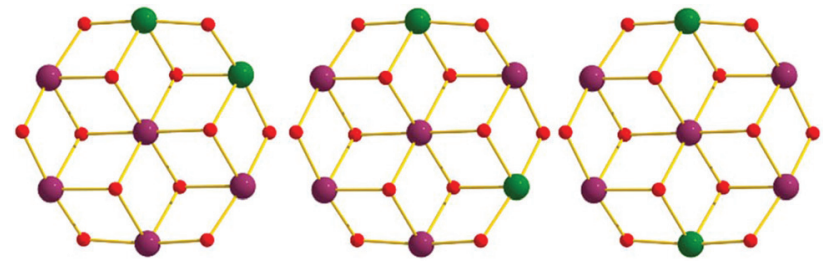

Fig. 3 Schematic representation showing the three isomers for compound 3: 1,2 (left), 1,3 (centre) and 1,4 (right).

We begin with a generic description of complexes 1-5. Complexes 1-3 and 5 are isostructural, crystallising in the trigonal space group $R \overline{3}$ with the asymmetric unit (ASU) containing only the central metal ion, one outer metal ion, two $\mathrm{hmp}^{-}$ ligands and two $\mathrm{ClO}_{4}{ }^{-}$anions. The structure (Fig. 2 and 3) is that of a centred metal hexagon in which the two $\mathrm{M}^{\mathrm{III}}$ ions are disordered around the outer $\left[\mathrm{M}_{6}\right]$ wheel. There are therefore two distinct metal sites in the $\left[\mathrm{M}_{2}^{\mathrm{III}} \mathrm{M}_{5}^{\mathrm{II}}\right]$ cluster, the central metal ion is always an $\mathrm{M}^{\mathrm{II}}$ ion (Co (1, 5), Fe (2), Mn (3)), which is bridged to the outer metal ions by six symmetry equivalent $\mu_{3}$-OR groups from six hmp ${ }^{-}$ligands. The central ion thus has a symmetry imposed, octahedral $\left(D 3_{\mathrm{d}}\right)\left[\mathrm{M}^{\mathrm{II}} \mathrm{O}_{6}\right]$ coordination sphere. The outer metal ions are all also symmetry equivalent, crystallographic disorder resulting in the $\mathrm{M}^{\mathrm{III}}$ ions being equally distributed around all six positions, each with a $2 / 3$ $\mathrm{M}^{\mathrm{II}}, 1 / 3 \mathrm{M}^{\mathrm{III}}$ occupancy, with an average charge of +2.33 . This was modelled as a 5:2 substitutional disorder ratio of metal centres by splitting the unique site into two separate parts with identical, constrained co-ordinates and anisotropic displacement parameters, and by fixing the occupancies such that they sum to give a $5: 2$ ratio of $\mathrm{M}^{\mathrm{II}}$ to $\mathrm{M}^{\mathrm{III}}$. The disorder gives three distinct structural isomers with the $\mathrm{M}^{\mathrm{III}}$ ions occupying outer ring positions $1,21,3$ or 1,4 in a ratio of $2: 2: 1$ (Fig. 3).

Around the ring, the metal ions are connected by one $\mu$-OR $\left(\mathrm{hmp}^{-}\right.$) group on the 'outside' of the wheel and one $\mu_{3}$-OR $\left(\mathrm{hmp}^{-}\right.$) group on the 'inside' of the wheel. Two terminally bonded $\mathrm{N}$-atoms from the $\mathrm{hmp}^{-}$ligands complete the octahedral coordination spheres on each metal ion. A total of twelve $\mathrm{hmp}^{-}$ligands therefore 'frame' the metal-oxygen core, six sitting above and six sitting below the metal ion plane. Charge balance is maintained through the presence of four $\mathrm{ClO}_{4}{ }^{-}$anions. Two sit one above/one below the plane of the metal core with their O-atoms closely associated to the three methylene groups of the hmp ${ }^{-}$ligands, with $\mathrm{Cl}-\mathrm{O} \cdots \mathrm{H}\left(\mathrm{CH}_{2}\right)$ distances of approximately $2.6 \AA$. These interactions occur between cations lying above and below the $\mathrm{ClO}_{4}{ }^{-}$ion creating offset cation-anion columns down the $c$-axis of the unit cell. The remaining two $\mathrm{ClO}_{4}{ }^{-}$anions sit parallel to the plane of the cage, with analogous inter-molecular cation-anion interactions creating $\mathrm{H}$-bonded sheets in the $a b$ plane. The overall result is an aesthetically pleasing topology reminiscent of a hexagonal close packed (hcp) array of cages viewed down the $c$-axis (Fig. S1†).

Compound 4 (Fig. 5) crystallises in the monoclinic space group $I 2 / a$, with half the molecular formula in the ASU. The structure is analogous to that seen for 1-3 and 5 but with the important exception that the two $\mathrm{Cr}^{\mathrm{III}}$ sites in the outer wheel are now not disordered, instead being localised in the 1,4 positions, i.e. trans to each other. The reason for this, and the lowering of crystallographic symmetry, is not clear but may be associated with the presence of Jahn-Teller (JT) distortions at the four peripheral $\mathrm{Cu}^{\mathrm{II}}$ sites $(\mathrm{Cu} 2-\mathrm{N} 3=2.032 \AA$ A $\mathrm{Cu} 2-\mathrm{O} 6=$ $2.402 \AA ; \mathrm{Cu} 3-\mathrm{N} 6=2.080 \AA$; $\mathrm{Cu} 3-\mathrm{O} 2=2.345 \AA$ ), and at the central $\mathrm{Cu}^{\mathrm{II}}$ site $\left(\mathrm{Cu} 1-\mathrm{O} 3 / \mathrm{O}^{\prime}=2.213 \AA\right)$. Charge balance is maintained through the presence of two $\mathrm{ClO}_{4}{ }^{-}$and two $\mathrm{NO}_{3}{ }^{-}$ anions. The cation-anion interactions are largely similar to that seen above, with the molecules forming layers in the $a b$ plane, with the $\mathrm{NO}_{3}{ }^{-}$anions lying between the planes and the $\mathrm{ClO}_{4}{ }^{-}$anions lying within the planes. However in this case the cations are not off-set, instead they sit directly above/below nearest neighbours along the $c$-axis of the unit cell (Fig. S2 and $\mathrm{S} 3 \dagger)$.

Complex 6 crystallises in the trigonal space group $R \overline{3}$, with the ASU containing the central $\mathrm{Cu}^{\mathrm{II}}$ ion $(\mathrm{Cu} 2)$, one $\mathrm{Al}^{\mathrm{III}}$ ion, one outer $\mathrm{Cu}^{\mathrm{II}}$ ion (Cu1), two $\mathrm{OH}^{-}$ions (O3, O4), two $\mathrm{hmp}^{-}$ ligands, one $\mathrm{ClO}_{4}{ }^{-}$anion and $1 / 3$ of an $\mathrm{NO}_{3}{ }^{-}$anion (Fig. $4 \mathrm{~b}$ ). 


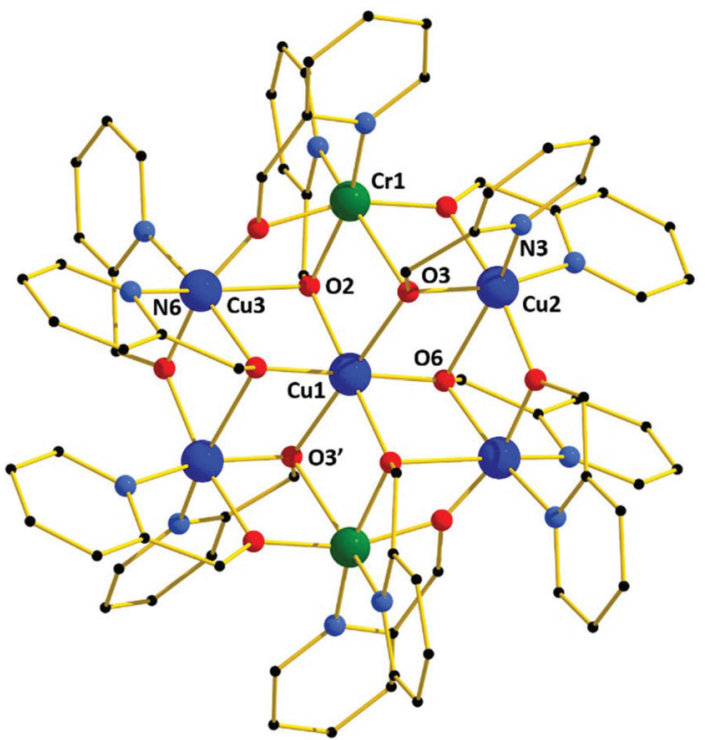

Fig. 4 Molecular structure of the cation of compound 4. Colour code: $\mathrm{Cr}=$ green, $\mathrm{Cu}=$ dark blue, $\mathrm{O}=$ red, $\mathrm{N}=$ light blue, $\mathrm{C}=$ black. $\mathrm{H}$-atoms, counter anions and solvent molecules omitted for clarity.

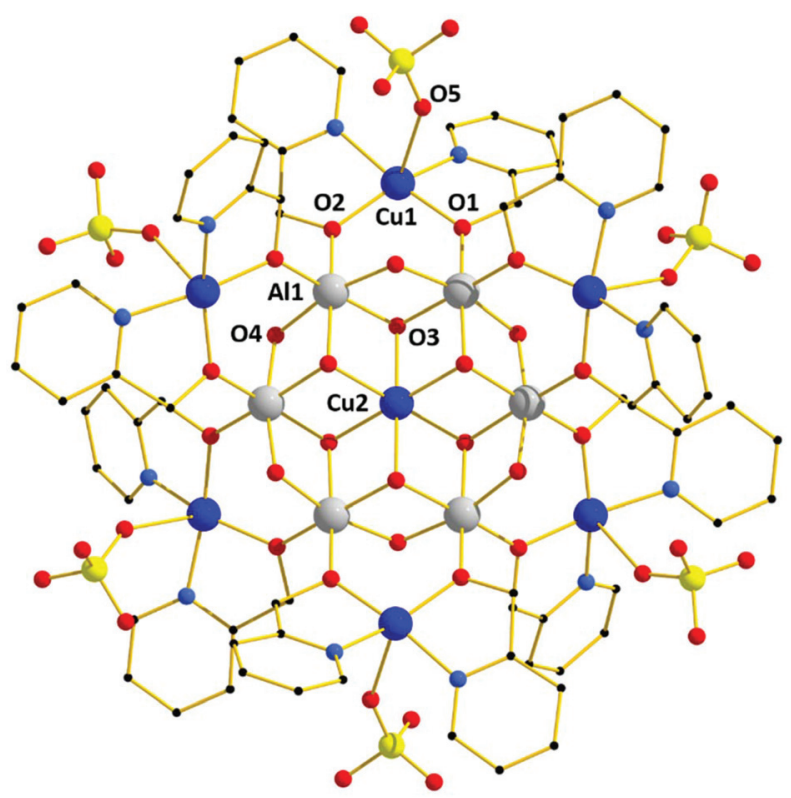

Fig. 5 Molecular structure of the cation of complex 6. Colour code: Al = silver, $\mathrm{Cu}=$ dark blue, $\mathrm{O}=$ red, $\mathrm{N}=$ light blue, $\mathrm{C}=$ black, $\mathrm{Cl}=$ yellow. $\mathrm{H}$ atoms and counter ions omitted for clarity.

The central core contains an Anderson-like $\left[\mathrm{Cu}^{\mathrm{II}} \mathrm{Al}_{6}^{\mathrm{III}}\right]$ wheel with an octahedral $\mathrm{Cu}^{\mathrm{II}}$ ion $(\mathrm{Cu} 2-\mathrm{O} 3=2.043 \AA)$ in the central position bridged to a ring of six $\mathrm{Al}^{\mathrm{III}}$ ions through six $\mu_{3}-\mathrm{OH}^{-}$ ions. $D 3_{\mathrm{d}}$ symmetry is imposed on $\mathrm{Cu} 2$ as it sits on a special position with a 3 -fold axis and an inversion centre. The $\mathrm{Al}^{\mathrm{III}}$ ions are further bridged to each other via six $\mu-\mathrm{OH}^{-}$ions (O4), and to edge-capping $\mathrm{Cu}^{\mathrm{II}}$ ions (Cu1) through the $\mu$-hmp ${ }^{-}$ ligands. The $\mathrm{Al}^{\mathrm{III}}$ ions are thus in octahedral geometries with
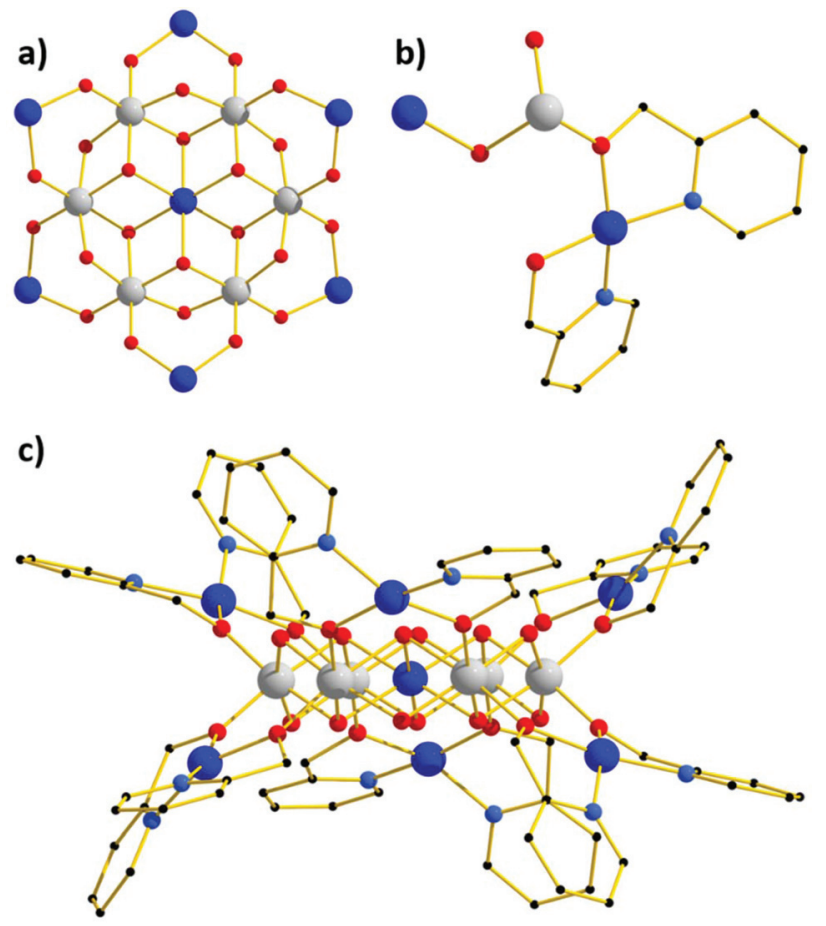

Fig. 6 (a) Metal-oxygen core of 6; (b) ASU; (c) side view highlighting the non-planarity of the outer $\mathrm{Cu}$ ions and associated chelating $\mathrm{hmp}^{-}$ ligands. $\mathrm{H}$-atoms, counter anions and solvent molecules of crystallisation omitted for clarity.

$\left[\mathrm{AlO}_{6}\right]$ coordination spheres, while the peripheral $\mathrm{Cu}^{\mathrm{II}}$ ions are square-based pyramidal with $\left[\mathrm{CuN}_{2} \mathrm{O}_{3}\right]$ coordination spheres, the fifth site being occupied by a $\mathrm{ClO}_{4}{ }^{-}$ion (Cu1-O5 = $2.637 \AA$ ). When viewed parallel to the central Anderson motif, it is clear that the metallic skeleton is not fully planar, with the six peripheral $\mathrm{Cu}^{\mathrm{II}}$ ions (Cu1) sitting alternately above and below the plane (Fig. 6). As these are chelated by the $\mathrm{hmp}^{-}$ ligands the latter also sit (six) above and (six) below the $\left[\mathrm{CuAl}_{6}\right]$ moiety. The packing of the molecules of 6 in the crystal (Fig. S4 and S5 $\dagger$ ) is akin to that seen for complexes 1-3 and 5, with offset columns of cations along the $c$-axis, the charge balancing $\mathrm{NO}_{3}{ }^{-}$counter ions lying between the sheets of cations present in the $a b$ plane. Nearest inter-cluster contacts exist between aromatic rings on neighbouring molecules with $\mathrm{C}(\mathrm{Ar})-\mathrm{C}(\mathrm{Ar})$ separations of $\sim 3.4 \AA, \mathrm{C}(\mathrm{Ar})-\mathrm{H}(\mathrm{CAr})$ of $\sim 2.8 \AA$ and $\mathrm{C}(\mathrm{Ar})-\mathrm{O}\left(\mathrm{ClO}_{4}^{-}\right)$of $\sim 3 \AA$. Note that the closest intermolecular $\mathrm{Cu} \cdots \mathrm{Cu}$ distance is $\sim 8.5 \AA$ (see magnetism and EPR sections below).

\section{Magnetometry}

Dc magnetic susceptibility $\left(\chi_{\mathrm{M}}\right)$ measurements were carried out on powdered polycrystalline samples of compounds 1-6 in a $B=0.1 \mathrm{~T}$ applied magnetic field over the temperature range $T$ $=2-300 \mathrm{~K}$, and are plotted as the $\chi_{\mathrm{M}} T$ product versus $T$ in Fig. 7 and 8.

For complexes 1-5 the experimental room temperature values of $\chi_{\mathrm{M}} T$ are close to the Curie constants expected for five 


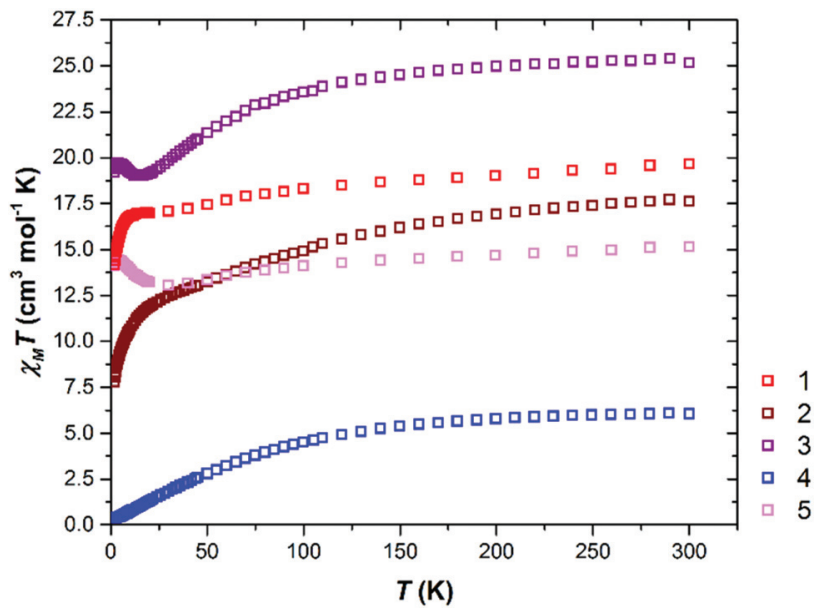

Fig. 7 Plot of the $\chi_{M} T$ product versus $T$ for complexes $1-5$ in an applied field, $B=0.1 \mathrm{~T}$

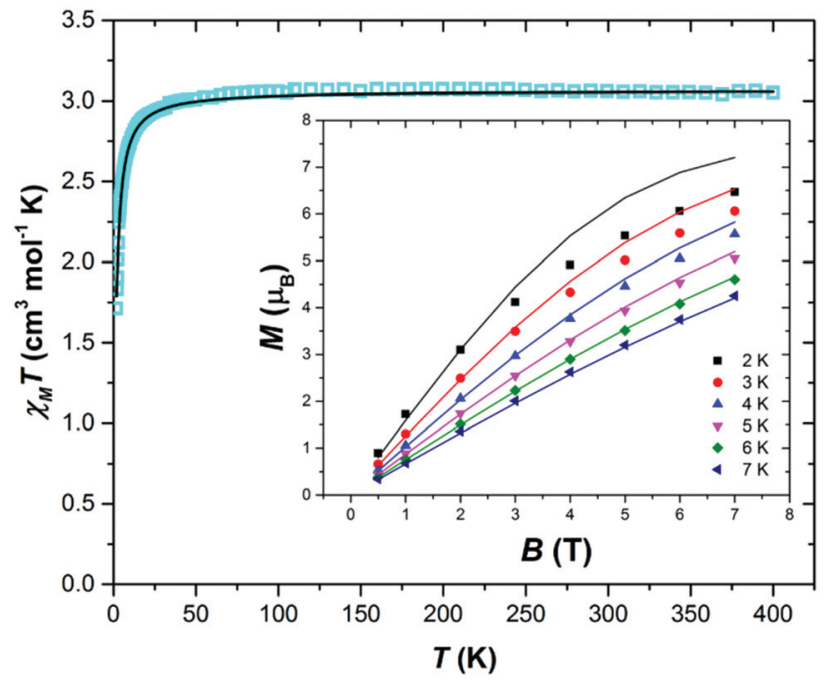

Fig. 8 Plot of the $\chi_{M} T$ product versus $T$ for complex 6 in an applied field, $B=0.1 \mathrm{~T}$. Inset: Plot of the magnetisation $(M)$ versus field $(B)$ data for complex 6 in the indicated field and temperature ranges. The solid black lines represent the simultaneous fit of the experimental susceptibility and magnetisation data.

and two non-interacting $\mathrm{M}^{\mathrm{II}}$ and $\mathrm{M}^{\mathrm{III}}$ ions, respectively; 1: $19.6 \mathrm{~cm}^{3} \mathrm{~K} \mathrm{~mol}^{-1}$ (expected $16.2 \mathrm{~cm}^{3} \mathrm{~K} \mathrm{~mol}^{-1}, g_{\mathrm{Cr}}=2.00, g_{\mathrm{Co}}=$ 2.30); 2: $17.7 \mathrm{~cm}^{3} \mathrm{~K} \mathrm{~mol}^{-1}$ (expected $18.2 \mathrm{~cm}^{3} \mathrm{~K} \mathrm{~mol}^{-1}, g_{\mathrm{Cr}}=$ $2.00, g_{\mathrm{Fe}}=2.20$ ); $3: 25.4 \mathrm{~cm}^{3} \mathrm{~K} \mathrm{~mol}^{-1}$ (expected $25.6 \mathrm{~cm}^{3} \mathrm{~K} \mathrm{~mol}^{-1}$, $g_{\mathrm{Cr}}=g_{\mathrm{Mn}}=2.00$ ); $4: 6.1 \mathrm{~cm}^{3} \mathrm{~K} \mathrm{~mol}^{-1}$ (expected $6.0 \mathrm{~cm}^{3} \mathrm{~K} \mathrm{~mol}^{-1}$, $\left.g_{\mathrm{Cr}}=2.00, g_{\mathrm{Cu}}=2.20\right) ; 5: 13.7\left(\right.$ expected $12.4 \mathrm{~cm}^{3} \mathrm{~K} \mathrm{~mol}^{-1}, g_{\mathrm{Cr}}=$ $2.00, g_{\mathrm{Co}}=2.30$ ). The temperature dependence of $\chi_{\mathrm{M}} T$ for all five complexes down to approximately $T \approx 25 \mathrm{~K}$ is rather similar, all decreasing slowly with decreasing temperature. For complex 1 the value of $\chi_{\mathrm{M}} T$ then plateaus at a value of $17.0 \mathrm{~cm}^{3} \mathrm{~K} \mathrm{~mol}^{-1}$, before decreasing to a value of 14.2 $\mathrm{cm}^{3} \mathrm{~K} \mathrm{~mol}^{-1}$ at $2 \mathrm{~K}$. For complexes 3 and 5 the value of $\chi_{\mathrm{M}} T$ increases to maximum values of 19.7 and $14.4 \mathrm{~cm}^{3} \mathrm{~K} \mathrm{~mol}^{-1}$, respectively. For complexes 2 and 4 the value of $\chi_{\mathrm{M}} T$ continues to decrease, reaching $T=2 \mathrm{~K}$ values of 7.8 and $0.5 \mathrm{~cm}^{3} \mathrm{~K} \mathrm{~mol}^{-1}$, respectively. The behaviour in each case is therefore consistent with the presence of competing exchange interactions, as observed and quantified for the structurally analogous $\left[\mathrm{Cr}_{2} \mathrm{Ni}_{5}(\mathrm{hmp})_{12}\right]^{4+}$ family of complexes. ${ }^{20}$ The positional disorder of the $\mathrm{Cr}^{\mathrm{III}}$ ions and resulting different isomers, the large number of different exchange interactions and, in the case of complexes, $\mathbf{1}, \mathbf{2}, \mathbf{5}$, the zero-field splitting effects of the $\mathrm{M}^{\mathrm{II}}$ ions precludes any detailed/quantitative analysis of the susceptibility data. Magnetisation $(M)$ versus field data, collected for 1-5 in the $T=2-7 \mathrm{~K}$ and $B=0.5-7 \mathrm{~T}$ temperature and field ranges (Fig. S6-S10 $\dagger$ ) are consistent with this picture, in each case $M$ rising rapidly with increasing $B$ without reaching saturation.

The dc susceptibility and magnetisation data for complex $\mathbf{6}$ is shown in Fig. 8. The high temperature $\chi_{\mathrm{M}} T$ value of $3.06 \mathrm{~cm}^{3}$ $\mathrm{K} \mathrm{mol}^{-1}$ is close to that expected for seven non-interacting $\left(s=\frac{1}{2}\right) \mathrm{Cu}^{\mathrm{II}}$ ions with $g=2.20\left(3.2 \mathrm{~cm}^{3} \mathrm{~K} \mathrm{~mol}^{-1}\right)$. This value remains constant in the $T=400-25 \mathrm{~K}$ temperature regime, before falling to a value of $1.7 \mathrm{~cm}^{3} \mathrm{~K} \mathrm{~mol}^{-1}$ at $T=2 \mathrm{~K}$. This is consistent with the presence of very weak antiferromagnetic exchange interactions between the $\mathrm{Cu}^{\mathrm{II}}$ ions, as would be expected from the presence of a 3-atom $(\mathrm{Cu}-\mathrm{O}-\mathrm{M}-\mathrm{O}-\mathrm{Cu})$ bridge between neighbouring paramagnetic sites. ${ }^{24}$ The data is invariant in measurements performed at different field strengths (Fig. S11 $\dagger$ ). The $\chi_{\mathrm{M}} T$ and magnetisation data were fitted simultaneously using isotropic spin-Hamiltonian (1) and the exchange interaction scheme depicted in Fig. 9, where the indices $i$ and $j$ refer to the interacting $\mathrm{Cu}^{\mathrm{II}}$ ions, $\mu_{\mathrm{B}}$ is the $\mathrm{Bohr}$ magneton, $B$ is the applied magnetic field, $g$ is the $g$-factor of the $\mathrm{Cu}^{\mathrm{II}}$ ions (fixed from the EPR with $g_{\|}=2.21$ and $g_{\perp}=2.06$ ), $\hat{S}$ is a spin operator and $J$ is the isotropic exchange interaction. Using this model, the best fit parameter was found to be $J=$ $-0.47 \mathrm{~cm}^{-1}$. This value is similar to that previously observed

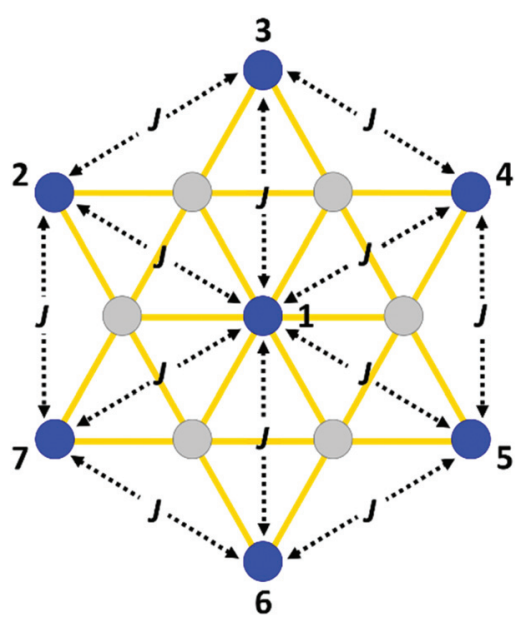

Fig. 9 Coupling scheme employed to fit the susceptibility and magnetisation data for complex 6 . Due to symmetry there are only two unique exchange pathways - $\mathrm{Cu}_{\text {central }}-\mathrm{Cu}_{\text {outer }}$ and $\mathrm{Cu}_{\text {outer }}-\mathrm{Cu}_{\text {outer }}$. Both are very similar and for simplicity we assume them to be equal. 


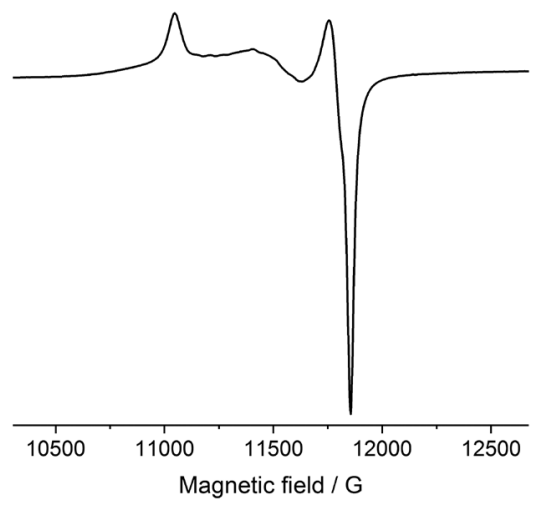

Fig. 10 Plot of the Q-band EPR spectra for complex 6 .

for $\mathrm{Cu}(\mathrm{II})$ ions bridged via diamagnetic metal ion (-O-M-O-) moieties. $^{24}$

$$
\hat{H}=\mu_{\mathrm{B}} B \sum_{i} g_{i} \hat{S}_{i}-2 \sum_{i \cdot j<i} J_{i j} \hat{S}_{i} \hat{S}_{j}
$$

Given the very small value of $J$, fitting was also attempted using a model in which intermolecular interactions (see the EPR section below) were also included via a mean-field approach, but all solutions remained inferior to that given above.

\section{EPR spectroscopy}

EPR spectra of a powdered sample of complex 6, measured at Q-band (ca. $34 \mathrm{GHz}$; Fig. 10), are consistent with tetragonal $\mathrm{Cu}(\mathrm{II})$ centres with near axially-symmetric $g$-values with " $g_{\|}$" = 2.06 and $" g_{\perp}$ " $=2.21$. There is no resolution of any fine structure and the spectra change little with variable temperature (beyond simple Curie behaviour), consistent with any intramolecular exchange interactions being very weak. However, there is no resolution of ${ }^{63,65} \mathrm{Cu}$ hyperfine structure, hence the $\mathrm{Cu}$ ions are not magnetically dilute. At the $g_{\|}$region, where the hyperfine interaction would be at its largest for tetragonal $\mathrm{Cu}(\mathrm{II})$, the (Lorentzian) linewidth (ca. $4 \mathrm{mT}$ ) is much narrower than the expected spread of the hyperfine multiplet $(50-60 \mathrm{mT}$ for $A_{\|}=0.015-0.02 \mathrm{~cm}^{-1}$ ): this is characteristic of an exchange narrowing regime where the intermolecular interactions in the lattice are comparable to the hyperfine interaction. Hence, care should be taken in interpreting the bulk magnetic properties of 6 from Hamiltonian (1) alone; it is also possible that the EPR $g$-values are characteristic of the lattice rather than the true molecular values.

\section{Conclusions}

The use of 2-pyridinemethanol in heterometallic 3d cluster chemistry has led to the isolation of a large family of complexes of general formula $\left[\mathrm{M}_{2}^{\mathrm{III}} \mathbf{M}_{5}^{\mathrm{II}}(\mathrm{hmp})_{12}\right]^{4+}$ where $\mathrm{M}^{\mathrm{III}}=\mathrm{Cr}$, Al and $\mathrm{M}^{\mathrm{II}}=\mathrm{Mn}, \mathrm{Fe}, \mathrm{Co}, \mathrm{Ni}, \mathrm{Cu}, \mathrm{Zn}$. These complexes all conform to the Anderson structure type describing a centred hexagon, in which the two $\mathrm{M}^{\mathrm{III}}$ ions are disordered around the outer wheel. The only exceptions are observed for $\mathrm{M}^{\mathrm{III}}=\mathrm{Cr}$ and $\mathrm{M}^{\mathrm{II}}=$ $\mathrm{Cu}$ where the same structure type forms but with the $\mathrm{M}^{\mathrm{III}}$ localised in the 1,4-positions, and for $\mathrm{M}^{\mathrm{III}}=\mathrm{Al}$ and $\mathrm{M}^{\mathrm{II}}=\mathrm{Cu}$ where a structurally related, but larger tridecanuclear $\left[\mathrm{M}_{6}^{\mathrm{III}} \mathbf{M}_{7}^{\mathrm{II}}\right.$ $\left.(\mathrm{hmp})_{12}\right]^{20+}$ species is formed. The Anderson type structures all display competing magnetic exchange interactions as one might expect from planar complexes containing triangular building blocks, while the $\mathrm{Cu}^{\mathrm{II}}$ ions $\left[\mathrm{M}_{6}^{\mathrm{III}} \mathbf{M}_{7}^{\mathrm{II}}(\mathrm{hmp})_{12}\right]^{20+}$ are very weakly antiferromagnetically coupled through either/both the intramolecular 3-atom $\mathrm{Cu}-\mathrm{O}-\mathrm{Al}-\mathrm{O}-\mathrm{Cu}$ moieties and dipolar, intermolecular interactions.

The modular assembly of large heterometallic cages is extremely rare, interestingly the only other example known is a family of Cr-based wheels which also show positional disorder at the metal sites. ${ }^{25}$ Building larger molecular cages based on the Anderson core in '2D' such that they resemble larger and larger fragments of the kagomé lattice is of fundamental interest to chemists and physicists studying the unusual physical phenomena resulting from spin frustration. ${ }^{26}$ The $\left[\mathrm{M}_{13}\right]$ structure type reported here is commonly observed in $\mathrm{Al}$ and $\mathrm{Ga}$ chemistry, ${ }^{27-29}$ but previous examples in 3d chemistry are limited to just $\mathrm{Ni}$ and Co. ${ }^{16,30}$

\section{Conflicts of interest}

There are no conflicts of interest to declare.

\section{Acknowledgements}

The authors thank the EPSRC for funding grants EP/N01331X/ 1, EP/P025986/1 and the UK National EPR Facility.

\section{Notes and references}

1 O. Kahn, Chem. Phys. Lett., 1997, 265, 109-114.

2 B. Sarkar, M. S. Ray, Y.-Z. Li, Y. Song, A. Figuerola, E. Ruiz, J. Cirera, J. Cano and A. Ghosh, Chem. - Eur. J., 2007, 13, 9297-9309.

3 R. Inglis, S. M. Taylor, L. F. Jones, G. S. Papaefstathiou, S. P. Perlepes, S. Datta, S. Hill, W. Wernsdorfer and E. K. Brechin, Dalton Trans., 2009, 9157-9168.

4 S. A. Magee, S. Sproules, A.-L. Barra, G. A. Timco, N. F. Chilton, D. Collison, R. E. P. Winpenny and E. J. L. McInnes, Angew. Chem., Int. Ed., 2014, 53, 53105313.

5 V. O. Garlea, S. E. Nagler, J. L. Zarestky, C. Stassis, D. Vaknin, P. Kögerler, D. F. McMorrow, C. Niedermayer, D. A. Tennant, B. Lake, Y. Qiu, M. Exler, J. Schnack and M. Luban, Phys. Rev. B: Condens. Matter Mater. Phys., 2006, 73, 024414.

6 J. Schnack, Dalton Trans., 2010, 39, 4677-4686.

7 R. D. Cannon and R. P. White, Prog. Inorg. Chem., 2007, 36, 195-298. 
8 T. Cauchy, E. Ruiz and S. Alvarez, J. Am. Chem. Soc., 2006, 128, 15722-15727.

9 K. R. Vignesh, S. K. Langley, C. J. Gartshore, B. Moubaraki, K. S. Murray and G. Rajaraman, Inorg. Chem., 2017, 56, 1932-1949.

10 G. Rajaraman, M. Murugesu, E. C. Sañudo, M. Soler, W. Wernsdorfer, M. Helliwell, C. Muryn, J. Raftery, S. J. Teat, G. Christou and E. K. Brechin, J. Am. Chem. Soc., 2004, 126, 15445-15457.

11 J. J. Henkelis, L. F. Jones, M. P. de Miranda, C. A. Kilner and M. A. Halcrow, Inorg. Chem., 2010, 49, 11127-11132.

12 R. W. Saalfrank, R. Prakash, H. Maid, F. Hampel, F. W. Heinemann, A. X. Trautwein and L. H. Böttger, Chem. - Eur. J., 2006, 12, 2428-2433.

13 M. Tesmer, B. Müller and H. Vahrenkamp, Chem. Commun., 1997, 721-722.

14 H. Oshio, N. Hoshino, T. Ito, M. Nakano, F. Renz and P. Gütlich, Angew. Chem., Int. Ed., 2003, 42, 223.

15 G. Aromí, S. Parsons, W. Wernsdorfer, E. K. Brechin and E. J. L. McInnes, Chem. Commun., 2005, 5038-5040.

16 J.-D. Leng, S.-K. Xing, R. Herchel, J.-L. Liu and M.-L. Tong, Inorg. Chem., 2014, 53, 5458-5466; Y. Peng, C.-B. Tian, H.-B. Zhang, Z.-H. Li, P. Lin and S.-W. Du, Dalton Trans., 2012, 41, 4740-4743.

17 A. K. Powell, S. L. Heath, D. Gatteschi, L. Pardi, R. Sessoli, G. Spina, F. Delgiallo and F. Pieralli, J. Am. Chem. Soc., 1995, 117, 2491-2502.

18 (a) Y.-K. Deng, H.-F. Su, J.-H. Xu, W.-G. Wang, M. Kurmoo, S.-C. Lin, Y.-Z. Tan, J. Jia, D. Sun and L.-S. Zheng, J. Am. Chem. Soc., 2016, 138, 1328-1334; (b) I. A. M. Pohl, L. G. Westin and M. Kritikos, Chem. - Eur. J., 2001, 7, 3438-3445.
19 E. K. Brechin, S. G. Harris, A. Harrison, S. Parsons, A. Gavin Whittaker and R. E. P. Winpenny, Chem. Commun., 1997, 653-654.

20 H. W. L. Fraser, G. S. Nichol, D. Uhrin, U. G. Nielsen, M. Evangelisti, J. Schnack and E. K. Brechin, Dalton Trans., 2018, 47, 11834-11842.

21 G. M. Sheldrick, Acta Crystallogr., Sect. C: Cryst. Struct. Commun., 2015, 71, 3-8.

22 O. V. Dolomanov, L. J. Bourhis, R. J. Gildea, J. A. K. Howard and H. Puschmann, J. Appl. Crystallogr., 2009, 42, 339-341.

23 L. Palatinus and G. Chapuis, J. Appl. Crystallogr., 2007, 40, 786-790.

24 R. Ruiz, M. Julve, J. Faus, F. Lloret, M. C. Muñoz, Y. Journaux and C. Bois, Inorg. Chem., 1997, 36, 3434-3439; M.-J. Heras Ojea, C. Wilson, S. J. Coles, F. Tuna and M. Murrie, Dalton Trans., 2015, 44, 19275-19281.

25 E. J. McInnes, G. A. Timco, G. F. Whitehead and R. E. Winpenny, Angew. Chem., Int. Ed., 2015, 54, 14244-14269.

26 C. Schröder, H. Nojiri, J. Schnack, P. Hage, M. Luban and K. Paul, Phys. Rev. Lett., 2005, 94, 017205.

27 S. L. Heath, P. A. Jordan, I. D. Johnson, G. R. Moore, A. K. Powell and M. Helliwell, J. Inorg. Biochem., 1995, 59, 785-794.

28 J. C. Goodwin, S. J. Teat and S. L. Heath, Angew. Chem., Int. Ed., 2004, 43, 4037-4041.

29 M. K. Kamunde-Devonish, D. B. Fast, Z. L. Mensinger, J. T. Gatlin, L. N. Zakharov, M. R. Dolgos and D. W. Johnson, Inorg. Chem., 2015, 54, 3913-3920.

30 Y. Peng, C.-B. Tian, Y.-H. Lan, N. Magnani, Q.-P. Li, H.-B. Zhang, A. K. Powell and S.-W. Du., Eur. J. Inorg. Chem., 2013, 5534-5540. 